\title{
DETERMINATION OF CADMIUM AND LEAD RESIDUES IN TISSUES AND ADMINISTRATION PROTECTIVE TREATMENT
}

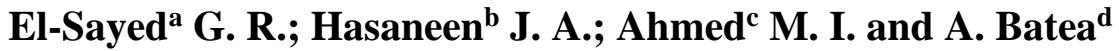 \\ ${ }^{a}$ Biochemistry Depart., Fac.ulty of Vet. Med., Mansoura Univ., Mansoura, Egypt. \\ ${ }^{\mathrm{b}}$ Chemistry Department, Faculty of Sci., Suez Canal Univ., Ismailia, Egypt. \\ ${ }^{\mathrm{c}}$ Manager of Wastewater Quality, Dakahliya Company, Egypt. \\ ${ }^{\mathrm{d}}$ Manager of Belqas Laboratory, Dakahliya, Egypt. \\ Email: Ahmed_batea2000@yahoo.com - Mansora, Egypt - 00201003094199
}

\begin{abstract}
Chronic exposure to heavy metals including lead and cadmium remains a serious problem for humanity. The current study aims to evaluate the impact of exposure to lead $(\mathrm{Pb})$ and cadmium $(\mathrm{Cd})$ on liver and kidney tissues of albino rats. 50 albino rats were divided equally into five groups respectively orally fed with lead acetate and cadmium chloride at $25 \mathrm{mg} / \mathrm{Kg}$ body weight, and 5.0 $\mathrm{mg} / \mathrm{kg}$. Body weight. The blood of each animal was collected and biochemical assays were conducted. Data were processed with SPSS 15.0. The results showed a significant increase in lead and cadmium residues in groups exposed to lead and cadmium. Not only that but also, the function of oxidative damage in $\mathrm{Pb}$ and $\mathrm{Cd}$ induced changes in the liver and kidney. Administration of thioctic acid as a treatment for these changes lead to significant improvement for these ratio. In conclusion, this study highlights a real problem of public health, in the light of thousands of patients receiving random therapy after exposure to heavy metals
\end{abstract}

Keywords: Lead acetate, Cadmium chloride, Biochemical parameters, Heavy metal, Thiocitic acid, Albino rats

\section{INTRODUCTION}

"Heavy metals" are of a specific gravity that is at least five times the specific gravity of water, which is 1 at $4{ }^{\circ} \mathrm{C}$. For example, the specific gravities of cadmium and lead are 8.7 and 11.3 , respectively (CRC, 1992). In recent years, 
the level of heavy metals, particularly lead has increased in air, water and soil in both urban and periurban areas (Gupta, 2007).

There is a lot of heavy metals in our environment: cadmium, chromium, cobalt, copper, lead, mercury, etc. Interestingly, small amounts of these elements are common in our environment and are actually necessary for good health (Jasim et al., 2012).

Although, humans were exposed to $\mathrm{Pb}$ through their environment and diet so, more than $75 \%$ of lead-exposure for the general population comes from ingestion (Patrick, 2006). Lead is considered a natural element and widespread in the environment. This heavy metal is still mined and added to many products including paints, eye cosmetics, gasoline, water pipes and health care supplies. The two major routes of lead entry into the body are the alimentary and respiratory tracts (Fischbein, 1992). Lead absorption and ingestion depends on many factors such as the particle size, physical form, gastrointestinal transit time and nutritional status of a person. Lead absorption increases, with the increase of age, making children more vulnerable to lead intoxication (Campbell et al., 2004).

On the other hand, when cadmium is given during lactation, to lactating mothers and newborn pups, cadmium chloride residues were found in the gastrointestinal tract of each (Saillenfait et al., 1992). In experimental animals application of cadmium affected tissue, caused blood vessel hemorrhage and resulted in cellular degeneration (Fréry et al., 1993).

The use of antioxidant rich food or antioxidant food supplements became immensely popular since many diseases have been associated with oxidative stress. Therefore, in the last decade, an increasing attention has been focused on free radical scavengers that are able to protect against aberrant effects of free radicals (Marangon et al., 1999). Administration of antioxidants is effective in reducing the toxic effects of some heavy metals (Inkielewicz-Stepniak and Knap, 2013).

Although preliminary studies have indicated possible benefit of thioctic acid in the treatment of alcoholic liver disease, thiocitic acid had no significant influence on the course of the disease (Marshall et al., 1982), so in our study we will investigate the protective effect of ALA from increasing of lead and cadmium concentration after intoxication of rats.

\section{MATERIALS AND METHODS}

\subsection{Materials:}

\subsubsection{Experimental animals:}

Fifty healthy white male albino rats, 8-10 weeks old and weighting 140-180 $\mathrm{gm}$, were used in the experimental investigation of this study. Rats were obtained from the Egyptian company for production of vaccines, sera, and drugs (Vacsera), Helwan branch. Animals were housed at faculty of veterinary 
medicine, Mansoura university in separate metal cages, fresh and clean drinking water was supplied ad-libitum.

\subsubsection{Chemical and drugs}

1- Lead acetate, rats received lead acetate $\left(1 / 20\right.$ of $\left.\mathrm{LD}_{50}\right)$ orally and daily at a dose level of (25 mg/Kg b.wt) (Debosree et al., 2012).

2- Cadmium chloride, rats received cadmium chloride $\left(1 / 20\right.$ of $\left.\mathrm{LD}_{50}\right)$ orally and daily at a dose level of $5.0 \mathrm{mg} / \mathrm{kg}$. Bodyweight (Van et al., 1981).

3- Thioctic acid (Alpha lipoic acid), Rats received Thioctic "Alpha lipoic" acid capsules dissolved in distilled water (freshly prepared) orally and daily at a dose of $54 \mathrm{mg} / \mathrm{kg}$ body weight as recommended by (Gruzman et al., 2004).

\subsubsection{Experimental design}

The rats were divided into five equal groups after accommodation to the laboratory conditions, one control and four experimental groups, each consisting of ten animals placed in individual cages.

Group I: (control group):

Rats of this group received drinking water without any chemical drugs, served as control for all experimental groups.

Group II: (Lead only exposed group)

Rats of this group received lead acetate $1 / 20$ of $\mathrm{LD}_{50}(25 \mathrm{mg} / \mathrm{Kg}$ b.wt) orally once per day over a period of 10 weeks as applied by (Debosree $\boldsymbol{e t}$ al., 2012).

Group III: (Cadmium only exposed group):

Rats of this group received cadmium chloride $1 / 20$ of $\mathrm{LD}_{50}(5.0 \mathrm{mg} / \mathrm{kg}$. body weight) orally and once per day over a period of 10 weeks as recommended by (Van et al., 1981).

Group IV: (lead acetate with thioctic acid "ALA" treated group)

Rats of this group received lead acetate orally and daily $(25 \mathrm{mg} / \mathrm{Kg} \mathrm{b} . \mathrm{wt})$ and treated with Thioctic acid "Alpha-lipoic acid" at a dose of $(54 \mathrm{mg} / \mathrm{kg}$ body weight orally /day) (Gruzman et al., 2004).

Group V: (Cadmium Chloride with thioctic acid "ALA" treated group): Rats of this group received cadmium chloride $(5.0 \mathrm{mg} / \mathrm{kg}$. body weight) and treated daily with Thioctic acid "Alpha-lipoic acid" at a dose level of $(54 \mathrm{mg} / \mathrm{kg}$ body weight orally /day) (Gruzman et al., 2004).

\subsubsection{Sampling for Tissues:}

Tissue (liver and kidney) samples were collected from all animals groups, control and four experimental groups two times along the duration of experiment at five and ten weeks from the beginning of rats exposure to lead, cadmium and antioxidant administrated.

\subsection{Methods and Instrumentation:}

\subsubsection{Varian Atomic Absorption spectrometry}

Samples were analyzed by Varian atomic absorption spectrometry (AAS) for the determination of lead and cadmium concentrations in liver and kidney 
"residue" at wavelength of 217 and $228 \mathrm{~nm}$ respectively (Varian $®, 2010)$ and (Skoog, 1992).

\subsubsection{Statistical analyses}

All statistical analyses were done by statistical software package "SPSS 15.0 for windows, SPSS Inc. Chicago, Illinois" and the GraphPad Prism package; v.5.0 (GraphPad Software, San Diego, CA). Animal's baseline characteristics were descriptively summarized and reported as mean \pm standard error of mean (SEM). Student's test was used to compare continuous variables. All tests were two-tailed. The result of the t-values was then checked on student's-t-table to find out the significance level ( $P$ value) as reported by (Pearson and Hartley, 1951).

\section{RESULTS}

\subsection{Lead and cadmium residues concentration in liver and kidney:}

Effect of thioctic acid treatment on lead and cadmium residues concentration in normal and intoxicated rats with lead and cadmium is illustrated in figures (1 and 2), respectively.

\subsubsection{Lead residue in liver}

Rats which exposed to lead, showed a significant increase in liver lead residues concentration after five and ten weeks from beginning the experiment comparing with normal control group where $P$ value was 0.0001 as presented in table (1). After administration of thioctic acid for lead intoxicated male rats after five and ten weeks from the beginning of experiment comparing with normal control group, there are a significant decrease in liver lead residues concentration where $P$ value was 0.0025 after five weeks and 0.0028 after ten weeks as presented in table (2).

\subsubsection{Lead residue in kidney}

Rats which exposed to lead, showed a significant increase in renal lead residues concentration after five and ten weeks from the beginning of the experiment comparing with normal control group where $P$ value was 0.0001 as presented in table (1). After administration of thioctic acid as in case of liver, there are a significant decrease in renal lead residues concentration where $P$ value was 0.0001 after five and ten weeks as presented in table (2).

\subsubsection{Cadmium residue in liver}

Rats which exposed to cadmium, showed a significant increase in liver cadmium residues concentration after five and ten weeks from the beginning of the experiment comparing with normal control group where $P$ value was 0.0001 as presented in table (3). After administration of thioctic acid for cadmium intoxicated as in lead case, there are a significant decrease in liver cadmium residues concentration where $P$ value was 0.0001 after five weeks and 0.0002 after ten weeks as presented in table (4).

\subsubsection{Cadmium residue in kidney}


Rats which exposed to cadmium, showed a significant increase in renal cadmium residues concentration after five and ten weeks from the beginning of the experiment comparing with normal control group where $P$ value was 0.0001 as presented in table (3). After administration of thioctic acid as in case of liver, there are a significant decrease in renal cadmium residues concentration where $\mathrm{p}$ was 0.0001 after five and ten weeks as presented in table (4).

Table 1. Lead levels (ppm) in renal and liver tissues after 5 and 10 weeks of rat's treatment with lead.

\begin{tabular}{llll}
\hline \multirow{2}{*}{ Type of tissues } & \multicolumn{2}{c}{ After 5 weeks of treatment } & \multirow{2}{*}{$\boldsymbol{P}$ value } \\
\cline { 2 - 3 } Controls & Pb treated animals & \\
\hline Renal tissues & $14.9 \pm 1.3$ & $133.8 \pm 0.3$ & $<0.0001$ \\
Liver tissues & $17.6 \pm 1.1$ & $46.8 \pm 1.7$ & 0.0001
\end{tabular}

\begin{tabular}{llll}
\hline \multirow{2}{*}{ Type of tissues } & \multicolumn{2}{c}{ After 10 weeks of treatment } & \multirow{2}{*}{$\boldsymbol{P}$ value } \\
\cline { 2 - 3 } & Controls & Pb treated animals & \\
\hline Renal tissues & $35.5 \pm 1.2$ & $176.4 \pm 2.7$ & $<0.0001$ \\
Liver tissues & $41.0 \pm 1.5$ & $69.3 \pm 1.9$ & $<0.0001$
\end{tabular}

Continuous variables were expressed as mean $\pm \mathrm{SEM} . \mathrm{Pb}=$ lead; $P>0.05$ is considered not significant, $P<0.05$ considered significant

Table 2. Role of thioctic acid on reduction of lead levels (ppm) in renal and liver tissues of lead intoxicated rats after 5 and 10 weeks of treatment.

\begin{tabular}{|c|c|c|c|}
\hline \multirow{2}{*}{ Type of tissues } & \multicolumn{2}{|c|}{ After 5 weeks of treatment } & \multirow{2}{*}{$P$ value } \\
\hline & Pb treated animals & Pb+TA cotreated animals & \\
\hline Renal tissues & $133.8 \pm 0.3$ & $36.5 \pm 1.3$ & $<0.0001$ \\
\hline Liver tissues & $46.8 \pm 1.7$ & $31.2 \pm 1.6$ & 0.0025 \\
\hline \multirow{2}{*}{ Type of tissues } & \multicolumn{2}{|c|}{ After 10 weeks of treatment } & P yalue \\
\hline & $\mathrm{Pb}$ treated animals & $\mathrm{Pb}+\mathrm{TA}$ cotreated animals & \\
\hline Renal tissues & $176.4 \pm 2.7$ & $67 \pm 1.1$ & $<0.0001$ \\
\hline Liver tissues & $69.3 \pm 1.9$ & $56.9 \pm 1.9$ & 0.0028 \\
\hline
\end{tabular}

Continuous variables were expressed as mean $\pm \mathrm{SEM} . \mathrm{Pb}=$ lead; $\mathrm{TA}=$ thioctic acid; $P>0.05$ is considered not significant, $P<0.05$ considered significant. 
Table 3. Cadmium levels (ppm) in renal and liver tissues after 5 and 10 weeks of rat's treatment with cadmium.

\begin{tabular}{|c|c|c|c|}
\hline \multirow[b]{2}{*}{ Type of tissues } & \multicolumn{2}{|c|}{ After 5 weeks of treatment } & \multirow[b]{2}{*}{$P$ value } \\
\hline & Controls & $\begin{array}{l}\text { Cd treated } \\
\text { animals }\end{array}$ & \\
\hline Renal tissues & $19.5 \pm 1.4$ & $511.0 \pm 14.6$ & $<0.0001$ \\
\hline Liver tissues & $16.8 \pm 1.1$ & $243.0 \pm 8.0$ & $<0.0001$ \\
\hline \multirow[b]{2}{*}{ Type of tissues } & \multicolumn{2}{|c|}{ After 10 weeks of treatment } & \multirow[b]{2}{*}{$P$ value } \\
\hline & Controls & $\begin{array}{l}\text { Cd treated } \\
\text { animals }\end{array}$ & \\
\hline Renal tissues & $19.1 \pm 0.8$ & $601.0 \pm 10.3$ & $<0.0001$ \\
\hline Liver tissues & $17.0 \pm 1.4$ & $298.3 \pm 7.6$ & $<0.0001$ \\
\hline
\end{tabular}

Table 4. Role of thioctic acid on reduction of cadmium levels (ppm) in renal and liver tissues of cadmium intoxicated rats after 5 and 10 weeks.

\begin{tabular}{|c|c|c|c|}
\hline \multirow[b]{2}{*}{ Type of tissues } & \multicolumn{2}{|c|}{ After 5 weeks of treatment } & \multirow[b]{2}{*}{$P$ value } \\
\hline & $\begin{array}{l}\text { Cd treated } \\
\text { animals }\end{array}$ & Cd+TA cotreated animals & \\
\hline Renal tissues & $511.0 \pm 14.6$ & $234.3 \pm 9.7$ & $<0.0001$ \\
\hline Liver tissues & $243.0 \pm 8.0$ & $101.0 \pm 5.5$ & 0.0001 \\
\hline \multirow[b]{2}{*}{ Type of tissues } & \multicolumn{2}{|c|}{ After 10 weeks of treatment } & \\
\hline & $\begin{array}{l}\text { Cd treated } \\
\text { animals }\end{array}$ & Cd+TA cotreated animals & $P$ value \\
\hline Renal tissues & $601.0 \pm 10.3$ & $319.0 \pm 10.7$ & $<0.0001$ \\
\hline Liver tissues & $298.3 \pm 7.6$ & $228.8 \pm 4.5$ & 0.0002 \\
\hline
\end{tabular}




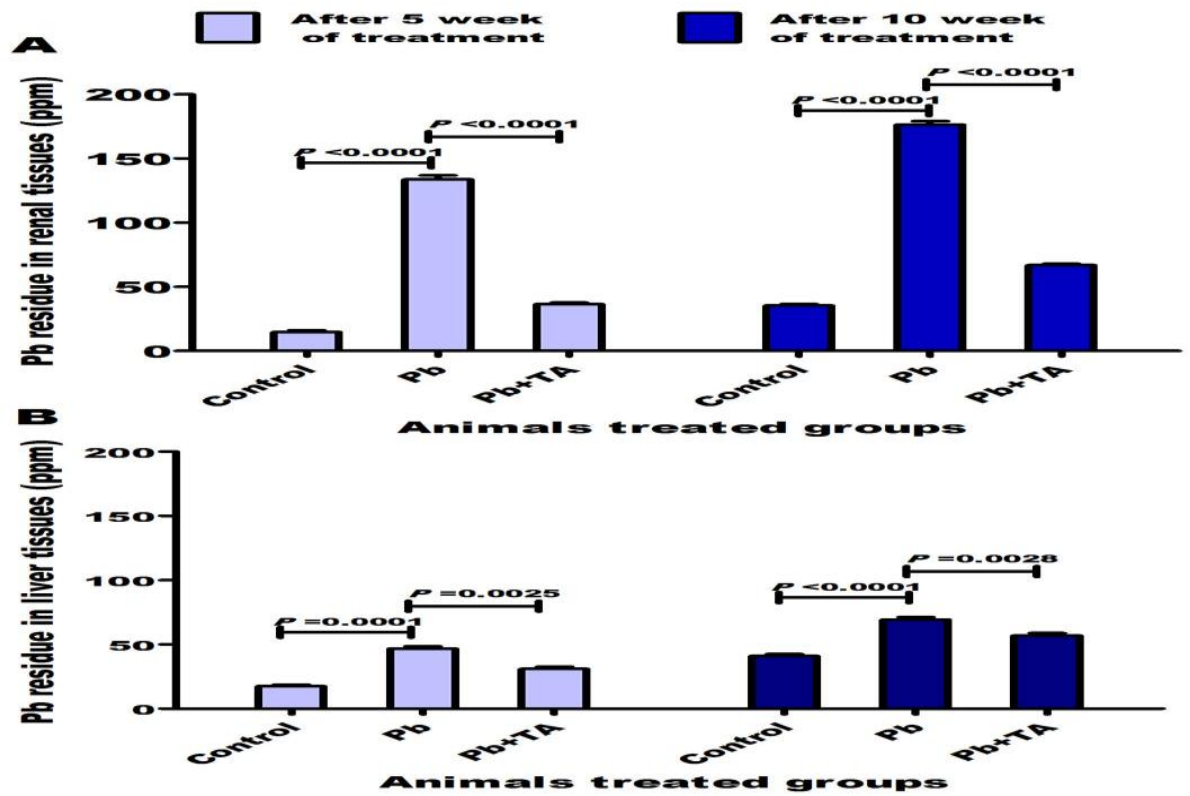

Figure 1. Lead residues in liver and kidney after five and ten weeks

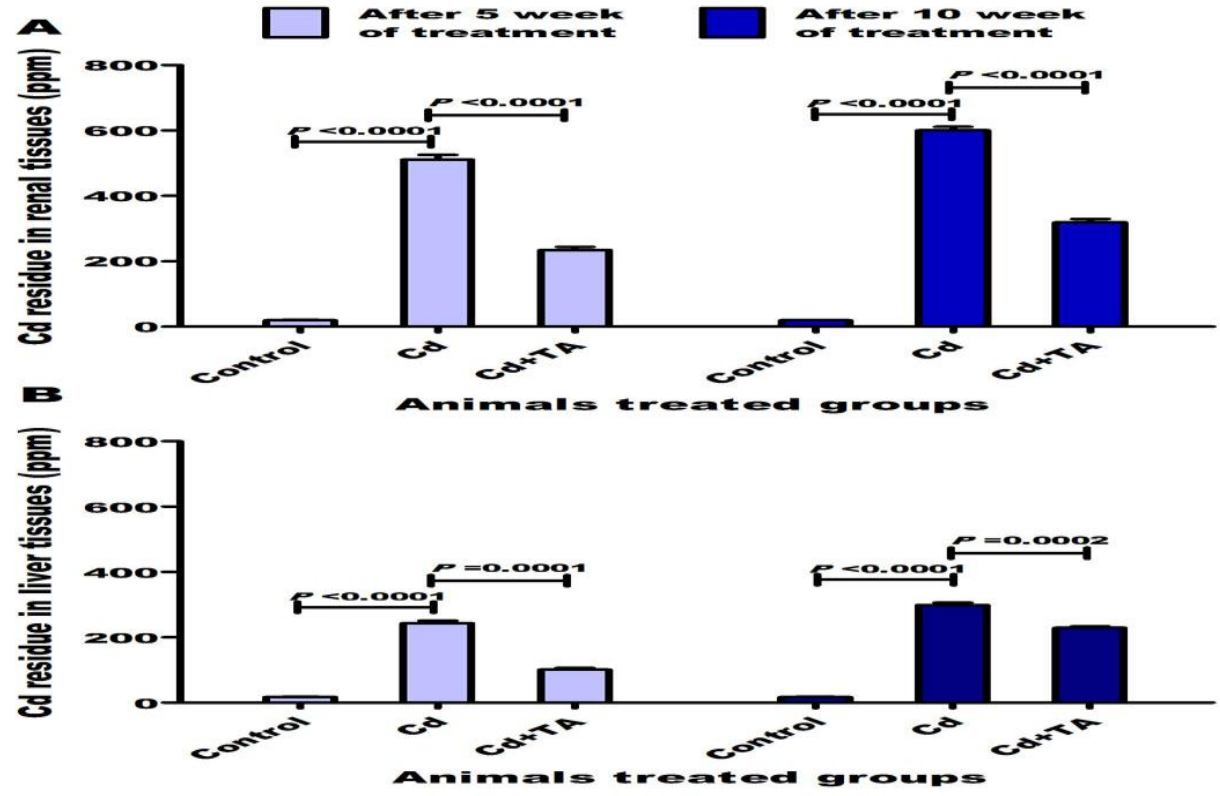

Figure 2. Cd residue in liver and kidney after five and ten weeks

\section{DISCUSSION}

From the above results presented in tables (1-4) and figures $(1,2)$, it was concluded that, a significant increase in Kidney and liver residues concentration from lead and cadmium was observed in lead and cadmium 
intoxicated male rats after five and ten weeks of the experiment when compared with control group. In case of lead intoxicated rats, these results came in accordance with the recorded data of (Liu $\boldsymbol{e t}$ al., 2012) who reported that, the lead levels in blood and kidney of lead-treated rats are significantly higher than those of control rats. Also, these results came in accordance with the recorded data of (Gaurav et al., 2011) who reported that, a significant increase in the toxic metal level in the liver, kidney and blood. Not only that but also, the function of oxidative damage in $\mathrm{Pb}$ and $\mathrm{Cd}$ induced changes in steroidogenesis in the liver and kidney (Dai et al., 2013).

Treatment with thiocitic acid ( $\alpha$-lipoic acid) to lead intoxicated rats, significantly reduced elevated Kidney and liver lead residues concentration and Liver lead residues concentration in lead intoxicated male rats after eight and ten weeks from the onset of treatment with $\alpha$-lipoic acid. These results came in accordance with the recorded data of (Osfor $\boldsymbol{e t}$ al., 2010) who reported that, alpha lipoic acid decrease lead levels in serum and kidney tissue of lead intoxicated rats compared to the control rats. The liver and the kidneys are also known to play a major role in the elimination of lead (Goyer and Chirian, 1979) and hence, account for the toxic actions (Lockitch, 1993).

In case of cadmium intoxicated rats, a significant increase in liver cadmium residues concentration was observed in cadmium intoxicated male rats after five and ten weeks of the experiment when compared with control group. These results came in accordance with the recorded data of (Gaurav et al., 2011), who reported that, a significant increase in the toxic metal level in the liver, kidney and blood with higher amount in the kidney which was evident from the data showing maximum accumulation of cadmium after 21 days. Also, (Ji et al., 2010) reported that, the absolute amounts of $\mathrm{Cd}$ in serum, livers, kidneys and testes were significantly increased in $\mathrm{Cd}$ treated mice as compared with controls. In addition, pubertal exposure to $\mathrm{Cd}$ also obviously increased the relative contents of $\mathrm{Cd}$ in mouse livers, kidneys against serum.

Treatment with thiocitic acid ( $\alpha$-lipoic acid) to cadmium intoxicated rats, significantly reduced elevated Kidney Cadmium residues concentration and Liver Cadmium residues concentrationin cadmium intoxicated male rats after four and ten weeks from the onset of treatment with thiocitic acid. These results came in accordance with the recorded data of (Packer et al., 1995) and (Biewenga et $\boldsymbol{a l}$., 1997) who reported that, LA has the ability to generate endogenous antioxidants, such as GSH.

\section{REFRENCES}

Campbell J. R., Rosier R. N., Novotny L., and Puzas J. E., (2004). "The association between environmental lead exposure and bone density in children". Env Hlth Persp. 112(11): 1200-1203. 
Campbell J. R., Rosier R. N., Novotny L., and Puzas J. E., (2004). "The association between environmental lead exposure and bone density in children". Env Hlth Persp. 112(11): 1200-1203.

CRC handbook of chemistry and physics (1992). Lide DR, editor. Boca Raton, FL: CRC Press.

Dai. S, Yin. Z, Yuan. G,Lu. H,Jia. R, Xu. J. Song. X, Li. L, Shu. Y, Liang. $X$, He. C, Lv. C. and Zhang. C., (2013). Qualification of metallothionein on the liver and kidney of rats by subchronic lead and cadmium in combination. environmental toxicology and pharmacology $36\left(\begin{array}{llll}2 & 0 & 1 & 3\end{array}\right)$ 1207-1216.

Debosree A., Ghosh M., Firdaus S. B., Mitra E., Dey M., and Adhyay D. B., (2012). Protective effect of aqueous leaf extract of Murraya Koenigi against lead induced oxidative stress in rat liver, heart and kidney: a dose response study, Asian Journal of Pharmaceutical and Clinical Research, Vol 5, Suppl 4.

Fischbein A., (1992). Occupational and environmental lead exposure. In: Rom WN. ed. Environmental and Occupational Medicine. 2nd ed. Boston: Little Brown; 1992: pp. 735-758.

Fréry N., Nessmann C., Girard F., Lafond J., Moreau T., Blot P., Lellouch J., and Huel G., (1993). Environmental exposure to cadmium and human birthweight. Toxicology, 79(2):109- 118.

Gaurav, D.; Preet, S. and Dua, K. (2011): Protective influence of dietary nutrients on antioxidant defense system in the blood of rats treated with cadmium. Adv. Applied Sci. Res., 2: 69-78.

Goyer R. A., Chirian M. G., (1979): Treatment of lead toxicity in rats. Life Sci.; 24: 433-438.

Gruzman, A., Hidmi, A., Katzhendler, J., Haj-Yehie, A., and Sasson, S. (2004). Synthesis and characterization of new and potent alpha-lipoic acid derivatives. Bioorg. Med. Chem. 12 (5): 1183-1190.

Gupta R. C., (2007). Veterinary toxicology. Basic and clinical principles. New York: Academic Press; pp. 663-725.

Inkielewicz-Stepniak I., and Knap N., (2013). Effect of exposure to fluoride and acetaminophen on oxidative/nitrosative status of liver and kidney in male and female rats. Pharmacol Rep., 64: 902-911.

Ji Y., Wang H., Liu P., Wang Q., Zhao X., Meng X., Yu T., Zhang H., Zhang C., Zhang Y., and Xu D., (2010): Pubertal cadmium exposure impairs testicular development and spermatogenesis via disrupting testicular testosterone synthesis in adult mice. Reproductive Toxicology, 29: 176-183.

Liu M.C., Liu X.Q., Wang W., Shen X.F., Che H.L., and Guo Y.Y. (2012). Involvement of microglia activation in the lead induced long-term potentiation impairment. PLoS ONE 2012;7: e43924. 
Lockitch G. (1993): Perspectives on lead toxicity. Clin Biochem.; 26: 371381.

Jasim S., AL-Wasiti E., and Subber S., (2012). Lead Exposure Effects on Batteries Manufacturing Factory Workers in Baghdad: IRAQI J MED SCI, 2012; VOL. 10(4).

Marangon K., Devaraj S., Tirosh O., Packer L., and Jialal I., (1999). Comparison of the effect of alpha-lipoic acid and alpha-tocopherol supplementation on measures of oxidative stress. Free Radic Biol Med 27: 1114-1121, 1999.

Marshall A. W., Graul R. S., Morgan M. Y., and Sherlock S., (1982). Treatment of alcohol-related liver disease with thioctic acid: a six month randomised double-blind trial. Gut 1982;23: 1088-1093.

Osfor, M.H., H.S. Ibrahim, Y.A. Mohamed and S.M. Ahmed, (2010): Effect of alpha lipoic acid and vitamin $\mathrm{E}$ on heavy metals intoxication in male albino rats. J. Am. Sci., 6(8): 56-63.

Packer L., Witt E. H., and Tritschler H. J., (1995). Alpha-lipoic acid as a biological antioxidant. Free Radical Biology and Medicine, 19(2): 227250.

Pearson, E. S. and Hartley, H. O., (1951). Charts of the power function for analysis of variance tests, derived from the non-central F-distribution. Biometrika; 38:112-130.

Skoog, D. A.; West, D. M. and Holler, F. J. (1992). Fudamentals of Analytical Chemistry. Saunders College Publishing, Fort Worth, USA

Van Vleet J.F., Boon D., Ferrans V.J., (1981). Induction of lesions of selenium-vitamin E deficiency in weanling swine fed silver, cobalt, tellurium, zinc, cadmium, and vanadium. Am. J. Vet. Res., 42: 789-799.

Varian ( ${ }^{\circledR}$ (2010). Operating Manual of the Varian AA240FS Atomic Absorption Spectrometer (AAS)- Australian 


\section{تعيين نسب الكادميوم والرصاص المتبقية في الأنسجة وتقديم العلاج الواقي لها}

أ.د. جهاد رمضان السيد ' ، أ.د. جيهان عبدالرازق حسانين، 'د. محمد ابراهيم احمدّ ، أحمد باتع فهي؛

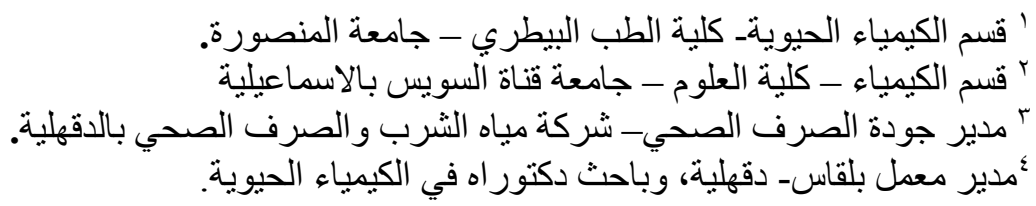

أجريت الدر اسة الحالية علي عدد • ه فأر من ذكور الفئر ان البيضاء، وتم تقسيم هذه الفئر ان الي خمسة مجمو عات كل مجمو عة تحتوي ( فئر ان، المجمو عة الاولي "الضابطة" لم تعطي أيا من المو اد الدخيلة، و المجموعة الثانية "المسمة بالرصاص" حيث تم تجريعهم بالرصاص يوميا عن طريق الفم بجرعة ه ب ملليجر ام لكل كيلو جر ام من وزن الجسم. والمجموعة الثالثة "المسمة بالكادميوم" تم تجريعهم بالكادميوم يوميا عن طريق الفم بجر عة ه ملليجر ام لكل كيلو جر ام من وزن الجسم و المجموعة الر ابعة "المسممة بالرصاص مع العلاج بمضاد التأكسد" وتم تجريعهم الرصاص بنفس الجرعة وتقديم مضاد الأكسدة "حمض الثايوكتلك" بجرعة قدر ها ــ ملليجر ام لكل كيلو جرام من وزن الجسم لمدة عشر اسابيع. و المجمو عة الخامسة "المسممة بالكادميوم مع العلاج بمضاد التأكسد" وتم تجريعهم الرصاص بنفس الجر عة وتقديم مضاد الأكسدة "حمض الثايوكتلك" ايضا بنفس الجرعة السابقة لمدة عشر اسابيع. و اخذ عينات الانسجة بعد ذبح الفئر ان بعد خمس و عثر أسابيع لتخضع للتحليل. وقد أظهرت النتائج زيادة ملحوظة في تركيز نسب الرصاص و الكادميوم في انسجة الكبد و الكلى مما يؤدي الي تلف هذه الخلايا، وبتقديم حمض الثايوكتيك كعلاج للتسمح ومعرفة مدي تغير هذه النسب المتبقية في خلايا الكبد و الكلى، و أسفرت النتائج عن انخفاض ملحوظ في هذه النسب مقارنة بالمجمو عات الضابطة، لذلك نوصي باستخدام حمض الثايوكتاك في علاج سمية تر اكم العناصر الثقيلة في كبد وكلي الحيو انات. 